\title{
Maize Fabric: Leading to a New Paradigm Shift
}

\author{
Sapna $^{1 *}$, Archna Jain ${ }^{2}$, Z. A. Dar ${ }^{3}$ and Asif M. Iqbal Qureshi ${ }^{3}$ \\ ${ }^{1}$ ICAR-National Bureau of Plant Genetic Resources, Pusa Campus, New Delhi 110012, India \\ ${ }^{2}$ Department of fabric and Apparel Sciences, Lady Irwin College, New Delhi 110001, India \\ ${ }^{3}$ Dryland Agriculture Research Station, SKUAST, Kashmir-190001, India \\ *Corresponding author
}

\section{A B S T R A C T}

Keywords

Maize, Fibres,

Cellulose

Article Info

Accepted:

10 April 2020

Available Online:

10 May 2020
Recycling of unmanaged agro-waste has always been a matter of great environmental concern to the developing countries. Recycling it into the fabric will be a major breakthrough in the textile as well as agricultural sector. Cornhusk is an agricultural byproduct having high potential for converting into fibres. Corn husk is bio cellulosic material and exhibits 80$87 \%$ cellulose and is a future renewable resource. It is eco-friendly, biodegradable, natural substitute to the synthetics and resistant to UV light as well. Present review focus on the technology involved, advantage, adaptability and futuristic approaches for fibre extracted from corn.

\section{Introduction}

With increasing global population has led to increase in fabric demand in the textile industry as well. However, increasing oil consumption is also leading to hike in the prices of the same and expected to be rise in future much more. In the past, people used to use their clothes for a longer period of time than the recent times. We are living in an era where consumers are more concerned towards quality with that of quantity of fabric. Now, jute and cotton are overburdened with this load; there is a need to look for alternate biorenewable sources for fabric. Fiber from maize husk is the most recent, eco-friendly and green textile concept because bio-based products always attract consumers. Maize is most versatile crop of the world, known as "Queen of Cereals".

Every part of maize is utilized for some or other purpose like food, feed and industrial product and nothing goes waste. It is also called as an industrial crop (Yadavet al., 2015). 
Husk is the outer shell of maize cob and leafy outer covering of ear of maize which protects the seed. Husk is a by-product of corn cultivation and generally discarded as biowaste, but it has high capacity of turning into the fabric being ecofriendly and biodegradable (Jain et al., 2018).

Approximately $69 \%$ of maize waste is produced out of 844 million tons of maize worldwide. Raw corn husk exhibits $80-87 \%$ cellulose and is a future renewable resource (Bhattacharya et al., 2018) whereas bleached cornhusk fibres were composed of $76 \%$ cellulose, $11.43 \%$ hemicelluloses, $\quad 7.5 \%$ lignin, $0.25 \%$ and $0.34 \%$ ash content (Jain et al., 2017).

A few preliminary studies have been done for efficient extraction and utilization of corn husk into fibre using different technologies. Extraction of natural cellulose fibres (Reddy and Yang 2005, Jain et al., 2017) and effect of various chemical parameters on these extracted husk fibres (Y1lmaz, 2013; Jain et al., 2017), effect of xylanase enzyme on fresh and dried husk (Y1lmaz et al. (2014), their characterization and increasing its stability by using banana sap (Kambli et al., 2018) and finally their physico-chemical properties to find out their suitability for various textile applications (Jain et al., 2017; Bhattacharya et al., 2018). Extracted corn fibre had properties between cotton and linen (Reddy and Yang, 2005)

\section{Benefits of maize fabric}

Using recycled raw material for textile industry has an added advantage of less energy consumption, less $\mathrm{CO}_{2}$, conservation of natural resources and other greenhouse gases (Jain et al., 2018) which are culprit of climate change. Compost ability (chemical dissolution of materials by bacteria or other biological means) and chemical recyclability is 100 per cent making it fully biodegradable (Chen et al., 1998). Major benefit of using it in India will be availability of raw material, reduced dependency on foreign companies and lower cost. Therefore, fabric from corn husk will be of special attraction to the textile industry.

\section{Stability of the fibres and technology involved}

Various technologies have been used to extract cornhusk fibres by different researchers like treatment using alkali, enzyme and bleach. Jain et al., 2017 analyzed fibres for various physico-chemical parameters and optimized alkali treatment with respect to concentration of sodium hydroxide, temperature and time of treatment. They got fibres with strength and fineness as $1.59 \mathrm{~g} / \mathrm{denier}$ and 130 denier respectively.

The fibres after final bleaching treatment had bundle strength of $1.33 \mathrm{~g} /$ denier and fineness of 86denier. Finally, fibres were assessed for their physio-chemical properties and it was found that the extracted fibres could be used for various textile applications other than apparel purposes.

Bhattacharya et al., 2018 extracted fibres using step-wise techniques of retting, fibre separation, yarn production and testing of the fibres (denier and stress). They used 20 litres of water for 1 kilogram of maize husk during retting process.

They got a yarn with average strain and stress value of $6.95 \%$ and $2.15 \mathrm{gpt}$ whereas the fineness of fibers extracted was 33.279 tex. They got better fibres than Yilmaz, 2013.Kambliet al., 2018 also characterized the physic-chemical properties of the fibres and they increased the stability of the fibres by using banana sap. 


\section{Futuristic approaches}

As we know that agro-waste contains substantial amounts of cellulose, mainly in fibrous form which is generally burned and adds to environmental pollution. Therefore, turning it into a useful commodity will benefit economically as well as environmentally having less pollution and greenhouse gases. Since, it is made up of agricultural waste, then; it will be biodegradable in nature. Generally byproducts are not utilized due to limited availability, processing difficulties and lesser adaptability.

Corn husk will be an exception to the all above constraints as it is freely available, comparatively easy processing and it has properties between cotton and linen as studied by few researchers. Very little work is done to explore the full potential of the cornhusk fibres.

Various techniques and studies can be explored to increase the stability of the fibres by mixing it with other natural fibres and materials. This will help agricultural as well as textile industry to produce green and ecofriendly fabric. The fabric will be skinfriendly being natural in nature and will help in eradication of skin issues created by synthetic fibres.

\section{References}

Bhattacharya, S. S., Mandot, A. A., Patel, M. H. 2018. Maize yarn production from fabricated equipment. Spinning Textile. 44-51.
Chen, P. L., Ruan, R. R., Addis,P. B., Li,Xu., Yi,Lun. 1998. Cellulose fiber based compositions and film and the process for their manufacture. U.S. Pat.No. 6,083,582.

Jain, A., Rastogi, D., Chanana, B. 2018. Utilization of cornhusk for textile usages, $J$ Basic and Applied Eng Res. 5 (5), 405-408.

Jain, A., Rastogi, D., Chanana, B., Parmar, M. S., Dhama, A. 2017. Extraction of cornhusk fibres for textile usages, IOSRJPolymer and Textile Eng. 4 (1), 29-34.

Kambli, N. D., Samanta, K. K., Basak,S., Chattopadhyay,S. K., PatilP. G., DeshmukhR. R. 2018.Characterization of the corn husk fibre and improvement in its thermal stability by banana pseudostem sap.Cellulose.25 (9), 5241-5257.

Reddy, N., Yang, Y. 2005.Properties and potentialapplications of natural cellulose fibers from cornhusks.GreenChem.7(4), 190-195.

Yadav, O. P., Hossain, F., Karjagi, C. G., Kumar, B., Zaidi, P. H. and Jat, S. L. 2015. Genetic improvement of maize in India: retrospect and prospects. Agri Res.4, 325-38.

Y1lmaz, N. D. 2013. Effect of chemical extraction parameters on corn husk fibres characteristics.Ind $J$ Fibre\& Textile Res, 38 (1), 29-34.

Yılmaz, N. D., Çalışkan, E.,Yılmaz, K. 2014. Effect of xylanase enzyme on mechanical properties of fibres extracted from undried and dried corn husks. Ind J Fibre \& Textile Res, 39 (1), 60-64.

\section{How to cite this article:}

Sapna, Archna Jain, Z. A. Dar and Asif M. Iqbal Qureshi. 2020. Maize Fabric: Leading to a New Paradigm Shift. Int.J.Curr.Microbiol.App.Sci. 9(05): 1341-1343. doi: https://doi.org/10.20546/ijcmas.2020.905.150 